\title{
Managing Equity Investment Risk and Rate of Return Risk in Islamic Banking: A System Thinking Approach
}

\begin{abstract}
Muhammad Farhan ${ }^{1}$, Hassan Mobeen Alam², Shaista Jabeen ${ }^{3}$
Abstract

This study aims to examine and explore the risk management practices with respect to Rate of Return Risk (RORR) and Equity Investment Risk (EIR) in the Islamic Banking Institutions (IBIs) of Pakistan through a systematic model which is called System Dynamic Model (SDM) by using system thinking methodology. This study has been conducted in three sequential phases to develop the qualitative System Dynamic Model for Rate of Return Risk Management and Equity Investment Risk Management. Firstly, the researchers developed preliminary Causal Loop Diagrams (CLD) based on the initial understanding achieved from the causal interconnections between various RORR and EIR characters through extensive literature review. Secondly, the researchers conducted semi-structured interviews with the experts to ratify, endorse and refine the initial CLD. Lastly, the data collected through interviews was analyzed to develop the final refined qualitative SDM. The study's findings indicate that the identification and measurement of the RORR and EIR in IBIs in Pakistan need to be strengthened by developing appropriate methodology. Moreover, the practices adopted by these financial institutions to mitigate and control the exposures of RORR and EIR are good and effective. This Qualitative SDM provides practical, constructive and productive understanding to the managers, policy-makers, regulators, shareholders and scholars regarding the RORR and EIR management mechanism of IBIs of Pakistan.
\end{abstract}

Keywords: Islamic Banking Institutions; Equity Investment Risk; System Dynamic Model; Mental Models; Rate of Return Risk

\section{Introduction}

The school of thought supporting the Islamic financial system demonstrates that the products of Islamic Banking Institutions (IBIs) are prone to less risk than the products of non-Islamic Banking Institutions due to their ethical structure (Schoon, 2016). Moreover, this viewpoint also advocates that the Islamic financial system is

1 Lecturer: Department of Management Sciences, National University of Modern Languages (NUML), Islamabad, Pakistan.Email:muhammad.farhan@numl.edu.pk

2 Professor: Hailey College of Commerce, University of the Punjab, Lahore, Pakistan.

3 Lecturer: Department of Management Sciences, Lahore College for Women University, Lahore, Pakistan.

\section{ARTICLE HISTORY}

11 Sep, 2020 Submission Received

27 Dec, 2020 First Review

09 Feb, 2021 Second Review

26 Feb, 2021 Accepted 
recession-proof with the capacity to resist economic shocks in a much better way than the conventional financial system (Eid, 2012). On the other hand, the opponents of IBIs claim that, along with the risk of conventional banking, the IBIs have their unique risks. According to this school of thought, as compared to conventional banking, Islamic banking is yet immature and risky (Errico \& Sundararajan, 2002). Who is right, and what is true? It is a continuous debate (Farhan, 2019). According to Akkizidis and Khandelwal (2008), these two opinions are crude, and it is not possible to consider them accurate. Moreover, the existing research on the Islamic financial system has not fully provided the solutions to these grey areas of Islamic finance (Eid \& Asutay, 2019). These authors further describe that Islamic finance is inherently riskier because it relies on equity financing rather than debt financing. Following the risky nature of Islamic banking and finance, it is critical to prudently investigate all the risks which are incorporated in the Islamic banking mechanisms as well the situation which influences the risk management, risk forbearance and risk environment of IBIs (Eid, 2012).

Due to its different liability structure and asset class, the IBIs have to bear double risk exposures, i.e., the risks of conventional banking and the risks particularly pertaining to Islamic banking (Abdul Rahman, Tafri, \& Aljanadi, 2010; Schoon, 2016; Iqbal \& Mirakhor, 2011; El Tiby, 2011; Hassan, 2009; Khan \& Ahmad, 2001). The risks specific to IBIs result from its compliance with Shariah (El Tiby, 2011; Khan \& Ahmad, 2001). Moreover, risk-sharing instead of risk transfer, considered as a ground of Islamic financial system, also exposes IBIs to few other risks such as Displaced Commercial Risk (DCR), Rate of Return Risk (RORR) and Equity Investment Risk (EIR) (El Tiby, 2011). Furthermore, IBIs have to face few risks, which are different from conventional banking institutions due to the unique risk exposures inherent in the Islamic modes of financing (Eid \& Asutay, 2019).

Financial institutions have developed various methods to improve their overall performance by mitigating various risks. Risk management is a financial management tool used by financial institutions for stability (Aldoseri \& Worthington, 2016). Risk management is a blend of capital and strategic planning, managing of financial and non-financial risks and asset-liability management (Greuning \& Iqbal, 2008). So, a comprehensive risk management structure is vital for the profitability and stability of a financial institution (Zainol \& Kassim, 2012).

Like their conventional peers, Islamic banking institutions face the challenge of efficiently understanding, defining, identifying, measuring, analyzing, monitoring and controlling different risk exposures across all asset classes and business lines while following Shariah principles. For effective implementation of these elements, the Islamic banking Institutions should develop and follow risk management system 
and process which includes development of sound and effective policies and procedures and risk management environment, maintaining proper risk identification, measurement, monitoring and mitigating mechanism, and ensuring strong internal controls (Khan \& Ahmad, 2001). Hence, a comprehensive and well-organized risk management framework is crucial for IBIs to improve their competency for competing in the market while minimizing their risk exposures (Iqbal \& Mirakhor, 2011).

Mastery of risks and execution of the latest risk management practices (RMP) are crucial for the survival and success of IBIs in the time of complications and black swans. The lightening growth of the Islamic banking system in the period of economic doubts requires the well-organized and effective implementation of RMP by these institutions to surpass their strategic, financial, and operational objectives (Shafique, Hassan \& Hussain, 2013). The failure of IBIs to proficiently implement risk management practices can result in their downfall, for instance, Islamic Bank Ltd of South Africa in 1997 and Ilhas Finance House of Turkey in 2000.

The concept of modern Islamic banking in Pakistan is not very old (Farhan \& Alam, 2018). However, despite strict competition from conventional banking, its growth is substantial in this era of complications. Following the rest of the world, the Pakistani Islamic banking system is exposed to non-conventional (risks relating to Islamic banking) and conventional (risks shared by conventional and Islamic banking) risks due to Shariah compliance, global market integration, product revolutions and financial deregulations. There were no separate risk management principles for IBIs in Pakistan until the SBP presented the recommendations in 2008, in addition to the guidelines issued for conventional banking in 2003. Hence caught the interest of the researchers to shed light on the exposures about EIR and RORR, which are specific to Islamic banking and did not get any guided mechanism in Pakistan until 2008.

Due to the lack of their own benchmark rate, practically, the Islamic Banking Institutions have to use the conventional standard rate for marking up their financing instruments. For instance, the mark-up rate in a Murabaha ${ }^{4}$ contract is calculated based on the standard market rate, such as London Interbank Offer Rate (LIBOR), by adding the risk premium. It remains fixed throughout the Murabaha contract. It may expose the IBIs to rate of return risk by using market interest rate as a standard to determine the return rate on deposits and financing (Zainol \& Kassim, 2012, IFSB, 2005). The rate of return risk is a complex risk because it exposes IBIs to various other risks. For example, the depositors may start to withdraw their deposits and transfer their funds to conventional financial institutions that offer a higher return on deposits, hence exposing IBIs to withdrawal risk. Excessive withdrawals may cause liquidity problems for an Islamic financial institution, leading to a more complex risk known as Liquidity 4 An Islamic mode of financing where the buyer and the seller agree to the cost plus profit of an asset being sold. 
risk (Farhan, 2019). Similarly, the equity investment risk is also specific to IBIs, and it is inherent in holding the equity instruments for investment purposes, especially in Musharkah ${ }^{5}$ and Mudarabah ${ }^{6}$ contracts. Like RORR, the equity investment risk is also complex and exposes IBIs to various other risks such as market risk, liquidity risk and credit risk (Eid \& Asutay, 2019).

Based on the background, in this research paper, the researchers aim to discover the risk management mechanism of IBIs in Pakistan with respect to RORR and EIR by establishing a qualitative system dynamic mechanism with the support of system thinking methodology. As explained earlier, both of these risks are specific to Islamic banking and very complex in nature. So, it is imperative to know the interconnections between different characters of RORR and EIR and their management in Pakistan. So, the researchers have used causal loop diagrams to find, understand and document the vigorous behaviour of different RORR and EIR variables in the risk management system of IBIs in Pakistan; understand different interconnected links of the system and use the available information to improve the system. The qualitative model has made the base of understanding that IBIs in Pakistan are effectively identifying, analyzing, mitigating and controlling the risk exposures relating to RORR and EIR or they are just throwing caution to the wind. In order to construct the qualitative models, the data was collected from the representatives of not only pure IBIs but also the conventional financial institutions with Islamic branches making this study different from others by providing a comprehensive visualization of RORR and EIR systems operating in Pakistan. Moreover, highlighting the risk management mechanism of the most important and ignored risks, especially in the local context, distinguishes this study from others.

\section{Literature Review}

\subsection{System thinking approach}

System thinking refers to the understanding of how the items can be processed systematically. It is a mean to find out the pattern of attitude by moving from specified events. It is a viewpoint seeking organized interconnections, accountable for the pattern of attitudes and events (Sherwood, 2002). This system explains that the grounds for understanding rests in creating the interconnections inside the system. The basis of the pattern of attitudes and events emerge from these interconnections (Bellinger, 2004). This approach is a blend of three constituents: elements (features), interconnections (the method of interrelations of these elements) and a purpose (a

$5 \mathrm{~A}$ partnership structure in Islamic finance where partners shares in the profits and losses of the business. 6 A profit and loss sharing partnership structure in which one partner provides funds and the other partner provides expertise. 
function), where the purpose is considered as the most critical component of the system (Meadows, 2008).

System thinking assists in finding out the solutions to problems in dynamic ways by widening our exposure and problem-solving aptitude. This technique brings to our knowledge that no perfect methods exist, and our choices influence other system areas. Before taking any action or reaching any conclusion, the system thinking approach allows us to investigate the issues more correctly and comprehensively. This approach allows us to integrate our thinking before reaching any conclusion based on literature findings. In addition, system thinking works as the best measure in defining system working. For instance, sketching the map of causal loop diagrams assists in visualizing the situation. These loops serve as beneficial tools to identify, describe and interrelate the human insights about the system (Goodman, 2016).

Causal Loop diagram helps in generating a channel to understand the dynamic and interrelated nature of the world. Usage of the Causal Loop diagram assists to develop an implicit and expressive system in preference to remain invisible (Kim, 1992; Sterman, 2001). As a result, system thinking has been applied by problem solvers, managers, professionals, researchers, legislators and policy-makers to know about the dynamic and interrelated nature of the world (Boersma, 2011; Kapp, Simoes, DeBiasi, \& Kravet, 2017; Leischow et al., 2008).

\subsection{Rate of Return Risk (RORR)}

Interest rate risk is not directly connected with IBIs as they strictly deal with the Shariah compliance, though they have to face a highly complex risk, known as RORR (Eid, 2012). The RORR is concerned with the uncertain yields on investment earned by IBIs (Rehman, 2016, IFSB, 2005).

Following the competitive environment, the business of IBIs and conventional financial institutions are operational concurrently (Lee, 2008). A sharp rise in interest with reference to mark-up rates; compel investors to transfer their reserves from IBIs to conventional banks. Correspondingly, the IBIs face some other risks like Liquidity Risk, Withdrawal risk and Displaced Commercial Risk. Suppose IBIs intimate the account holders about $5 \%$ expected return on investments; however, the market rate increases to $7 \%$., a higher rate than the predicted rate. Such a situation leads accountholders to expect a higher return on investment, exposing IBIs to RORR.

It has been explained earlier that the nature of the rate of return risk is intricate, and as a result, IBIs may have to face some more complicated and interrelated risk. These risks are briefly explained as under: 


\subsubsection{Displaced Commercial Risk (DCR)}

DCR arises due to variations in the rate of return paid under the pressure of profit and loss accountholders and the return gained from the investments (IFSB, 2005). This variation is the generation of a low rate of return by the IBIs compared to the competitors, irrespective of following the Shariah rules. It leads investors to invest their resource somewhere else. To cope with this situation, IBIs leave a specific percentage of profit (Rehman, 2016). This sacrificed portion of profit by the IBIs to protect investors is a commercial decision under the approved guidelines of the board of directors (SBP, 2008).

\subsubsection{Withdrawal Risk (WR)}

WR deals with the withdrawal of excessive deposits by the depositors from the IBIs. As per the SBP, this extraordinary withdrawal on behalf of depositors can occur based on three reasons: gained return is lesser than expected rate of return; some issues about the financial soundness of IBIs; incapacity of IBIs to use the Shariah principles for various financial contracts and transactions (SBP, 2008).

\subsection{Equity Investment Risk (EIR)}

ERI is associated with the equity investments of IBIs. The baseline of these investments is Mudarabah and Musharkah contracts (Akkizidis \& Khandelwal, 2008). These contracts are used for investments in stock purchases in stock markets and distinctive projects and portfolio investments. The IBIs have to face Market Risk, Credit Risk and Liquidity Risk due to these equities. These risks cause financial instability for IBIs, which results in the loss of invested equity (Eid, 2012; Greuning \& Iqbal, 2008; IFSB, 2005; Rehman, 2016).

Some essential considerations for EIR that have been presented by the SBP (2008) are as under:

- Proficient Mudarabah and Musharkah partners

- Improved observation of Mudarabah and Musharkah agreements

- Valuation of governing and legal situation

- Valuation of risk caused by new technology and risk of replacement by innovation

- A pool of trustworthy information for investment evaluations

The financial sector flourishes as per the active role of risk management. How- 
ever, as far as Islamic banks are concerned, the concept of risk management needs to be explored (Rehman, Ibrahim, Tohiri.,Suryaputri, \& Vitariamettawatym, 2016) as the vast literature is available on Non-Islamic banks (Ratnovski, 2013; Lee, 2015; Cebenoyan \& Strahan, 2004). The risk management studies with respect to Islamic banking have been carried out in Gulf countries (Ali \& Naysary, 2014; Abu Hussain \& Al-Ajmi, 2012; Abdullah, Shahimi, \& Ismail,.2011; Hassan, 2011), some other countries (Rahman, Ibrahim, Tohirin, \& Suryaputri, 2016; Muhammad, 2016; Hafez, 2015) and minimal studies in Pakistan (Khalid \& Amjad, 2012; Ahmad et al., 2013). Considering Pakistan's context, the investigation of pure Islamic banking risks, precisely rate of return risk and equity investment risk, is still unexplored (Farhan, 2019). Therefore, it captures the attention of researchers to explore this hidden aspect.

\section{Methodology}

\subsection{The research philosophy}

As the purpose of this research paper is to examine and explore the risk management practices with respect to the rate of return risk and equity investment risk in the Islamic Banking Institutions of Pakistan. This aim has been achieved by ascertaining, understanding and sketching a map of causality among various characters of the rate of return risk and equity investment risk and the risk management practices with respect to these risks.

Interpretivism contends the achievement of reality in terms of social structures, i.e. shared meanings, mechanisms, language, and consciousness (Myers, 2009). It has been claimed that human beings are complex entities. Each human being experiences and realizes the same reality in different ways with their respective causes of execution in the world. Moreover, it has also been argued that for recognizing human actions, the world must be seen with the view of performers making their performances (Thompson, 2015). So, an interpretive philosophical stance enables the researchers to achieve the study objectives (Farhan, 2019). Moreover, the researchers have observed the Pakistani Islamic Banking Institutions as organizations. These organizations are required by the regulatory authority to develop a risk management mechanism, which these institutions enforce through their staff. Therefore, in this study, the objectivism position has been taken by the researchers by considering the IBIs as a tangible entity that is different from the employees who manage them.

\subsection{The research design}

The researchers have taken the stance that what is studied (the case) is more important than how it is studied (the method). So, this research is conducted as a case 
study by taking all the IBIs as a case. Taking the IBIs as a case helped the researchers thoroughly investigate their risk management system with respect to the rate of return risk and equity investment risk within their real-life settings. The population of the study is all those Islamic Banking Institutions that are offering banking services in Pakistan. There are five Islamic banks in Pakistan and seventeen conventional banks offering Islamic banking services. The sampling frame consists of all pure Islamic banks ( banks offering only Islamic banking services) and non-Islamic banks with Islamic branches. The data has been collected from the senior risk managers of the selected Islamic Banking Institutions. For this purpose, the researchers used the purposive sampling method. This is an economical, time-saving and effective non-probability sampling technique when there are limited respondents who can effectively help achieve the research objectives (Black, 2012). Senior risk managers are experts in the risk management system and the most appropriate persons for getting the responses to achieve the study objective. The researchers approached each bank's senior risk manager to collect the data for making the findings clear and comprehensive. However, the researchers managed to arrange interviews from five Islamic banks and fifteen respondents from conventional banks offering Islamic services. So, the researchers were able to get the response from twenty banks out of the population of twenty-two banks. The data was collected from the target respondents through face-to-face semi-structured interviews.

\subsection{The research strategy}

The nature of existing research is to explore the equity investment and rate of return risk management framework of Islamic banking institutions of Pakistan, so the crucial aspect is how this objective can be achieved. The possible working of the system can be described by studying the system via literature, confirm and amend it by assimilating theoretical and practical aspects, applying changes, and placing this investigation in terms of traditional research. But, this research has incorporated the system thinking approach to envisioning the functioning of the system by CLD (by showing the graphical representation of the comprehensive functioning of an intricate system). The system infers that the foundation of understanding is based on establishing interrelationships within the system. These interrelationships provide the root cause of behavioural configurations and measures we intend to assume (Bellinger, 2004). Moreover, the graphical presentation of the mentioned risk management structure makes it easy to understand.

This study has been conducted in three sequential phases to develop the qualitative system dynamic model for Rate of Return Risk Management and Equity Investment Risk Management. Firstly, the researchers developed a preliminary CLD 
based on the initial understanding of the causal interconnections between various Rate of Return Risk Management and Equity Investment Risk Management characters through extensive literature review. Secondly, the researchers conducted face to face semi-structured interviews with the experts to ratify, endorse and refine the initial CLD. Lastly, the data collected through interviews was analyzed to develop the final refined qualitative system dynamic model. The interview guide was developed by following the guidelines given by eight sets of legitimate reservations of Goldratt's theory of constraints. The purpose of these sets is to identify the basis that develops the validity of preliminary CLD (Dettmer, 1997). These sets include point of strength, point of weakness, usefulness, practical relevance, logical structure, cause sufficiency, causal existence and clarity of the initial CLD. The respondents were asked on these categories to develop the qualitative model.

The model development process has a core section, i.e. model authentication, to provide a gurantee that it successfully represents the reality of the actual system (Alasad, Motawa, \& Ougunlana, 2013). The system thinking approach allows the respondents to rectify, endorse and validate the initial causal loop diagrams by making corrections with pencil on the paper. The eight legitimate reservations given by Goldratt's theory of constraints enable the researchers to modify the themes highlighted in the initial causal loop diagrams, which were developed based on literature review and initial understanding of the researchers. The respondents provided their response on the usefulness, practical relevance, logical structure, cause sufficiency, causal existence and clarity of the initial CLD. Moreover, the respondents also commented on the complexity of the diagram, missing information and unnecessary information which required modification. The responses of the respondents clarified, corrected and endorsed the initial CLD. These interviews became a bridge to reach the validated causal loop diagrams after incorporating the experts' recommendations.

\section{Development of System Dynamic Model}

\subsection{Managing Rate of Return Risk (MRRR)}

The policy-makers of IBIs are directed by policy guidelines issued by the SBP on RORR to formulate a risk management framework for identifying and evaluating the probable effects of market elements that may cause fluctuation in Rate of Return on investments in comparison to the expected rate of return for PLS account holders. The IBIs are also advised to assess their reliance on current deposits, as unusual withdrawals on account of current deposits would have an adverse impact on the potential rate of return. These guidelines recommend some essential prerequisites regarding vigorous RORR management, such as well-organized management, knowledgeable board, proficient employees, and dynamic systems and processes. 
IBIs need to understand, recognize, measure and analyze all those factors, dimensions and elements that elevate RORR. It is recommended that the IBIs use different methods as per the intensity and nature of their investments. These methods vary from gapping method to refined simulation or vigorous frameworks to assess expected cash-flow variabilities. Moreover, IBIs are also recommended to utilize different balance sheet methods to minimize their return risk rate. In addition, at the time of evaluating RORR exposures, IBIs must focus on the non-contractual behavioural maturity of the transactions in relation to their operational settings and changing market situations.

Moreover, the IBIs in Pakistan are obliged to formulate strategies and practices to reach the anticipation level of their PLS depositors. The SBP has also conveyed that it is a commercial choice of IBIs to share their profits with the PLS account holders. Such a decision must be based on the guidelines and procedures approved by their Board of Directors. Figure 1 demonstrates the initial CLD for MRORR developed based on initial understanding achieved through literature review and personal knowledge of the researchers on the causal interconnections among various characters of the rate of return risk. The figure has been developed through Vensim 7 software which demonstrates these connections graphically by two subsystem balancing loop diagrams (B6 and B7). The balancing loops try to take things to the desired position and keep them there. In other words, from the way things are to the way things should be.

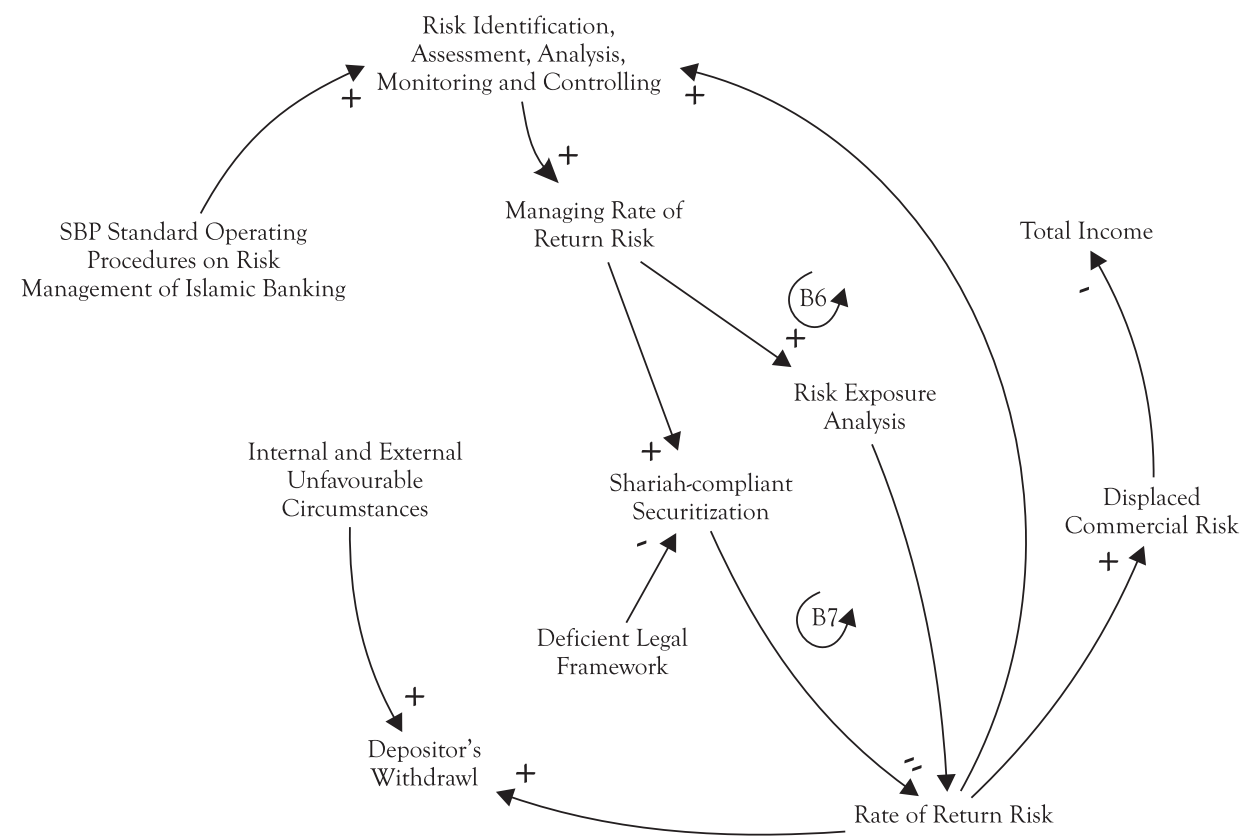

Figure 1: Initial CLD of Managing RORR 
This figure depicts that standard operating procedures issued by the SBP lead the Islamic banking institutions to formulate a system of risk management with respect to the rate of return risk (SBP, 2008). The B6 loop highlights that the risk exposure analysis can counter the rate of return risk. The B7 loop indicates the adoption of Shariah-compliant securitization to control the rate of return risk. Moreover, the literature indicates that rate of return risk may lead to the withdrawal of deposits and displaced commercial risk (See Conceptual Framework), which has been mapped in this figure.

\subsubsection{System dynamic model for Managing Rate of Return Risk (MRRR)}

In the context of IBIs of Pakistan, subsystem causal loop diagram is used to explain MRRR. Figure 2 demonstrates one reinforcing feedback loop (R41) and three balancing feedback loops (B44, B45 and B46). The model has been developed by refining, ratifying and validating the initial CLD on the basis of semi-structured interviews.

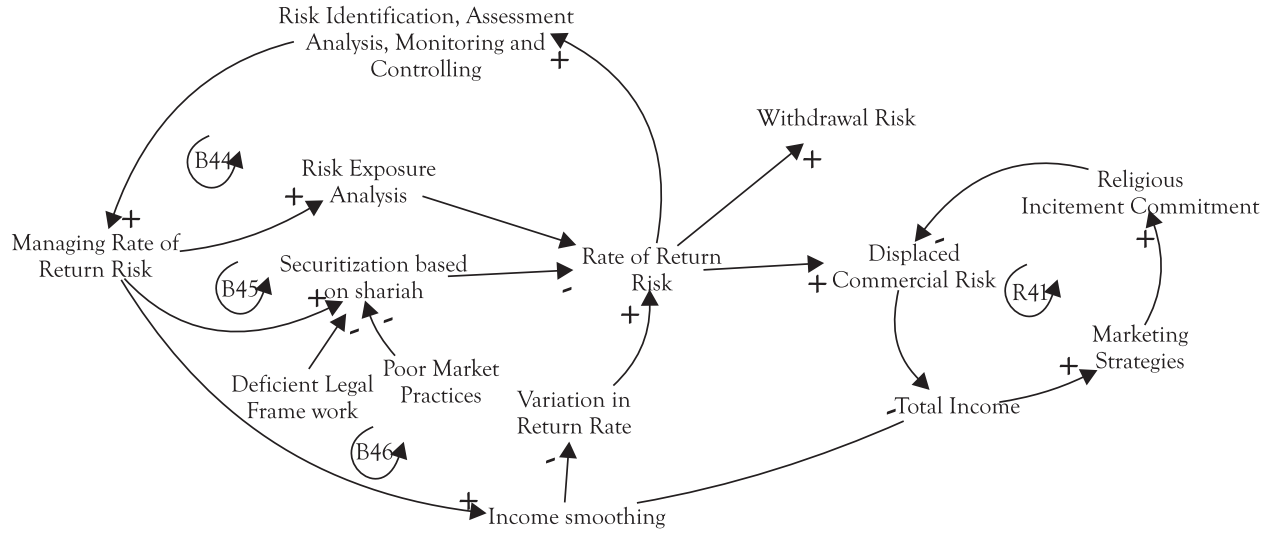

Figure 2: Validated CLD for Managing RORR in IBIs

The B44 loop (Comprising: MRRR $\rightarrow$ Risk Exposure Analysis $\rightarrow$ RORR $\rightarrow$ RIAAMC) demonstrates that IBIs of Pakistan assign risk exposure analysis to their proficient staff. This analysis is carried out on the risk exposures which emerge from the consolidated balance sheet positions of IBIs. These employees perform two-fold functions, i.e. they observe the variations in expected profit ratios by focusing on the predictions of market conditions and proficiently investigating the associated factors of RORR.

The B45 loop (Comprising: MRRR $\rightarrow$ Securitization based on Shariah $\rightarrow \mathrm{RORR} \rightarrow$ RIAAMC) demonstrates that fluctuating market circumstances induce IBIs of Pakistan for securitizing their liabilities and assets. This Shariah-based securitization is not lim- 
ited to finance the products, but it is also used to minimize the ROR risk exposures by these institutions (Wahyudi, Rosmanita, Prasetyo, \& Putri, 2015). It is important to understand that the Shariah-compliant securitization is a measure adopted by IBIs to synchronize the maturity of assets with liabilities through investment in a group of existing Shariah-compliant securities (issuance of Sukuk).

The B46 loop (Comprising: MRRR $\rightarrow$ Income Smoothing $\rightarrow$ Variation in Return Rate $\rightarrow$ RORR $\rightarrow$ RIAAMC) exhibits that IBIs have to arrange funds from their reserves to meet the extraordinary expectations of their PLS account holders. The return provided to these account holders is adjusted at the expense of IBI's own profit. The IBIs create these reserves to meet the expectations of their PLS depositors to alleviate the risk of withdrawals of deposits.

The R41 reinforcing feedback loop (Comprising: Total Income $\rightarrow$ Marketing Strategies $\rightarrow$ Religious Incitement/Commitment $\rightarrow$ Displaced Commercial Risk) illustrates that an increase in the income of IBIs exerts influence on them to devote more funds on various marketing campaigns to pinch the religious obligations of not only the existing but also the potential account holders. The religious motivation of accountholders reduces their expectations about high returns, even if the returns on securities are underperforming. The R41 behaviour shows that IBIs of Pakistan spend a part of their income on various campaigns to induce the religious incitement and commitment of account holders.

Overall, Figure 2 explains the involvement of IBIs of Pakistan to fulfil the prudential requirements of the SBP to manage the RORR. The root cause of this risk is the adverse variations between the actual return provided by the investment and the predicted rate of return by the account holder (Wahyudi et al., 2015). The RORR in the IBIs of Pakistan is managed with the help of effective risk exposure analysis. The IBIs use effective balance sheet procedures (issuance of Shariah-compliant securitization tranches) to mitigate the risk exposure. However, ineffective legal structures and inefficient market practices are the causes of limited potential in this Islamic securitization (Jobst, 2007; Zainol \& Kassim, 2012). Moreover, inadequate performance of the securities with reference to the market exposes IBIs of Pakistan to displaced commercial risk and withdrawal risk. For managing such risks, income smoothing and different marketing strategies are used by Islamic Banking Institutions of Pakistan. The model indicates that IBIs are good at mitigating and controlling various RORR exposures. Still, there is a need to use more effective methods to identify and assess these risk exposure. 


\subsection{Managing Equity Investment Risk (MEIR)}

For equity investment risk management, three principles have been given by the SBP. Some general guidelines also accompany these principles. These guidelines are explained as under:

The IBIs are advised, before making Mudarabah or Musharkah contracts, to conduct enhanced due diligence relating to the risk profile of their prospect Musharak or Mudarib partners. The complete record of the persons participating in the management and the quality of the project must be considered in the risk profile. Moreover, the legal and regulatory environmental aspects must be emphasized at the time of risk evaluation. These aspects range from tax policies, subsidies, tariffs, quotas to variations in the frameworks regarding the viability of the contract.

The IBIs must emphasize appropriate strategies to manage risk and regulate the disclosure of equity investment projects relating to Mudarabah and Musharkah contracts. Moreover, these strategies must focus on the investment category, risk acceptability, expected returns, and predicted holding time. The development of a framework to evaluate and control the risks inherent in getting, retaining and finally exiting the equity investments must be addressed as per the regulatory guidelines. Moreover, it is also advised by the SBP to formulate a system for monitoring and evaluating the performance of ongoing investments made by IBIs as partners. IBIs must identify and monitor the risk transformation at various levels of investment lifecycles.

The IBIs are accountable to ensure the consistency and accurateness of their valuation techniques. They are also obliged to determine the potential effects of these techniques on the valuation and dispersal of income. Mutual consensus must be developed between IBIs and Mudarib / Musharak partners about these techniques. To involve autonomous parties for audit and investment appraisal, IBIs must be in harmony with Mudarib or Musharik partner to ensure the visible valuation and provision of financial benefits.

The IBIs are also guided to process the exit strategies relating to equity investment, consisting of augmentation and exoneration arrangements for Musharkah and Mudarabah contracts. Moreover, IBIs must employ Shariah-compliant risk-reduction measures to safeguard equity investments from the potential impact of capital loss. Figure 3 demonstrates the initial CLD for MEIR developed on the basis of initial understanding achieved through literature review and personal knowledge of the researchers on the causal interconnections among various characters of the rate of return risk. The figure has been developed through Vensim 7 software which demonstrates these connections graphically by two subsystem balancing loop diagrams (B4 and B5). 


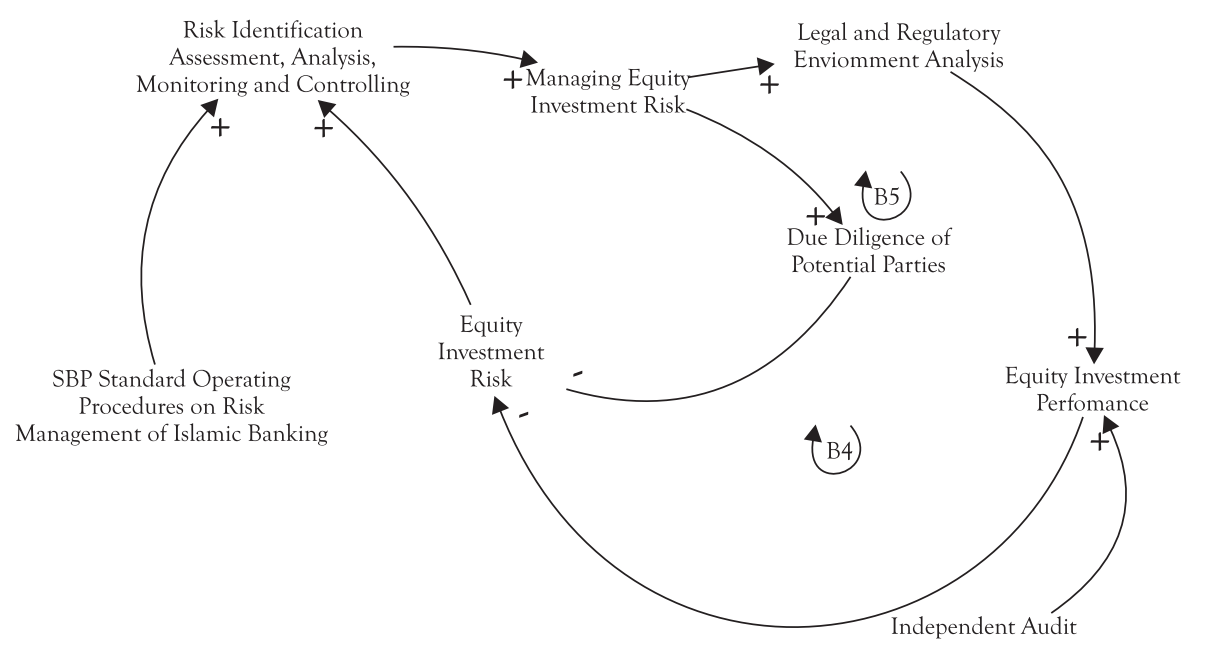

Figure 3: Initial CLD of Managing EIR

This figure depicts that standard operating procedures issued by the SBP lead the Islamic banking institutions to formulate a system of risk management with respect to the equity investment risk (SBP, 2008). The B4 loop highlights that proactive regulatory and legal environment analysis can positively impact equity investment performance, which can negatively impact the Equity investment risk. The B5 loop indicates that thorough due diligence of potential clients can reduce the equity investment risk.

\subsubsection{System dynamic model for Managing Equity Investment Risk (MEIR)}

MEIR make reference to the management of such risk exposures, which are inherent in retaining the equity investments. In Pakistan, this risk is intrinsic in Mudarabah and Musharkah contracts (SBP, 2008). The management of exposures regarding the retention of equity investment, especially for trade and liquidity, is part of market risk. It is not incorporated in the EIR guidelines issued by the SBP.

Figure 4 demonstrates the subsystem causal loop diagram of MEIR. This causal loop diagram consists of three balancing loops (B47, B48 and B49).

In figure 4, the B47 loop (Comprising: MEIR $\rightarrow$ Pre-contract Analysis $\rightarrow$ Equity Investment Risk $\rightarrow$ RIAAMC) signifies that the IBIs investigate the quality of equity investment partners, associated investment activity, and working issues before finalizing equity contract. The analysis also contains an investigation of the history of group members of management, quality of investment feasibility and enhanced due diligence of the people to be part of the Musharkah or Mudarabah contracts to reduce the EIR.

The B48 loop (Comprising: MEIR $\rightarrow$ Observing Investment Functioning $\rightarrow$ 


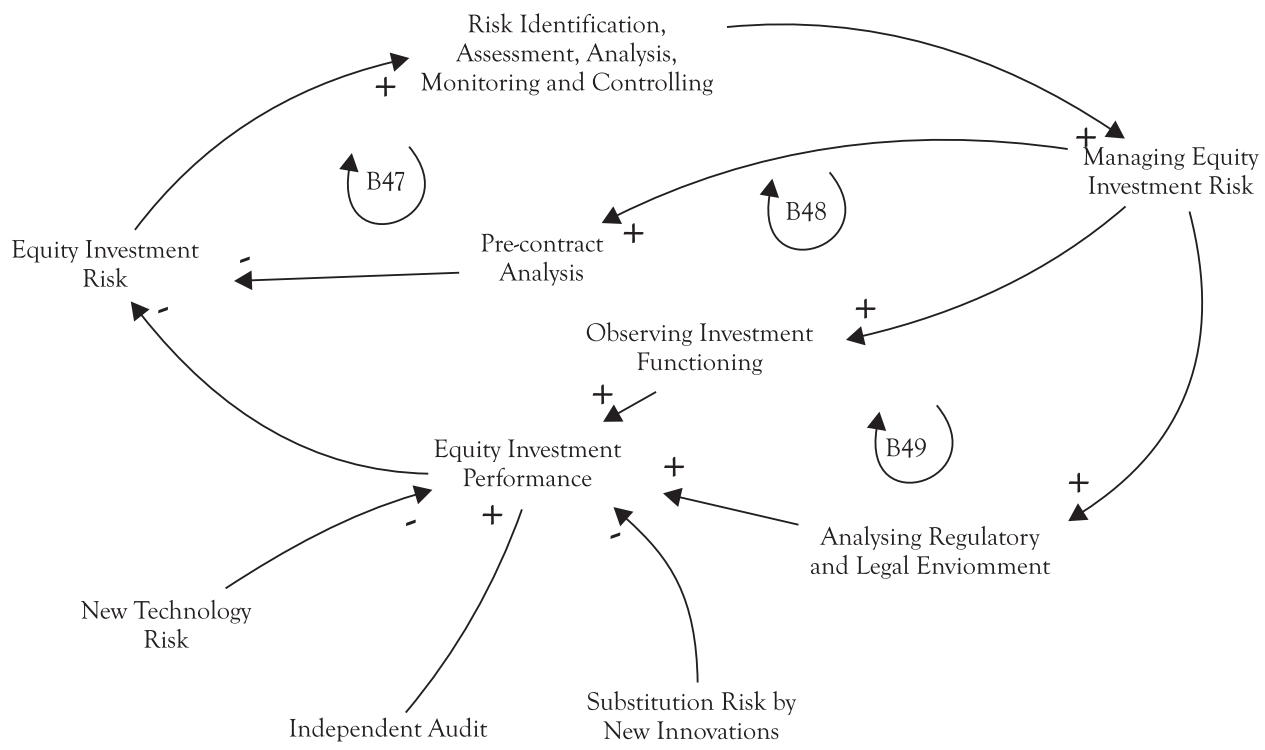

Figure 4: Validated CLD for Managing EIR in IBIs

Equity Investment Performance $\rightarrow$ RIAAMC) demonstrates that the Pakistani IBIs continuously evaluate the operations and performance of their equity investment projects. It ranges from timely meeting with the business partners, examining the fairness of financial reporting, investigating the Shariah-based processes to confirm the best equity investment performance.

The B49 loop (Comprising: MEIR $\rightarrow$ Analysing Regulatory and Legal Environmentl Equity Investment Performance $\rightarrow$ RIAAMC) demonstrates that local IBIs monitor the legal and governing situation to protect the equity investment from hostile effects. This analysis consists of policies pertaining to subsidies, taxation, quotas, tariffs and any other sudden policy change that can influence the value and feasibility of the equity investment.

Overall, Figure 4 explains that as per the instructions of SBP, local IBIs employ proficient equity risk analysis to control the EIR. This analysis comprised examination before contract, investigation of the regulatory and legal environment, and analysis of after contract performance. This proactive technique assists IBIs to ensure that relevant processes and controls remain present throughout the life of an equity investment. Still, the risk of technology transformation and risk of replacement by innovation influence equity investment performance. In addition, the independent parties also stimulate the performance of equity investment through regular audit (Eid \& Asutay, 2016). Just like the model of MRORR, this model also indicates that IBIs are good 
in mitigating and controlling various EIR exposures, but there is a need to use more effective methods to identify and assess these risk exposure

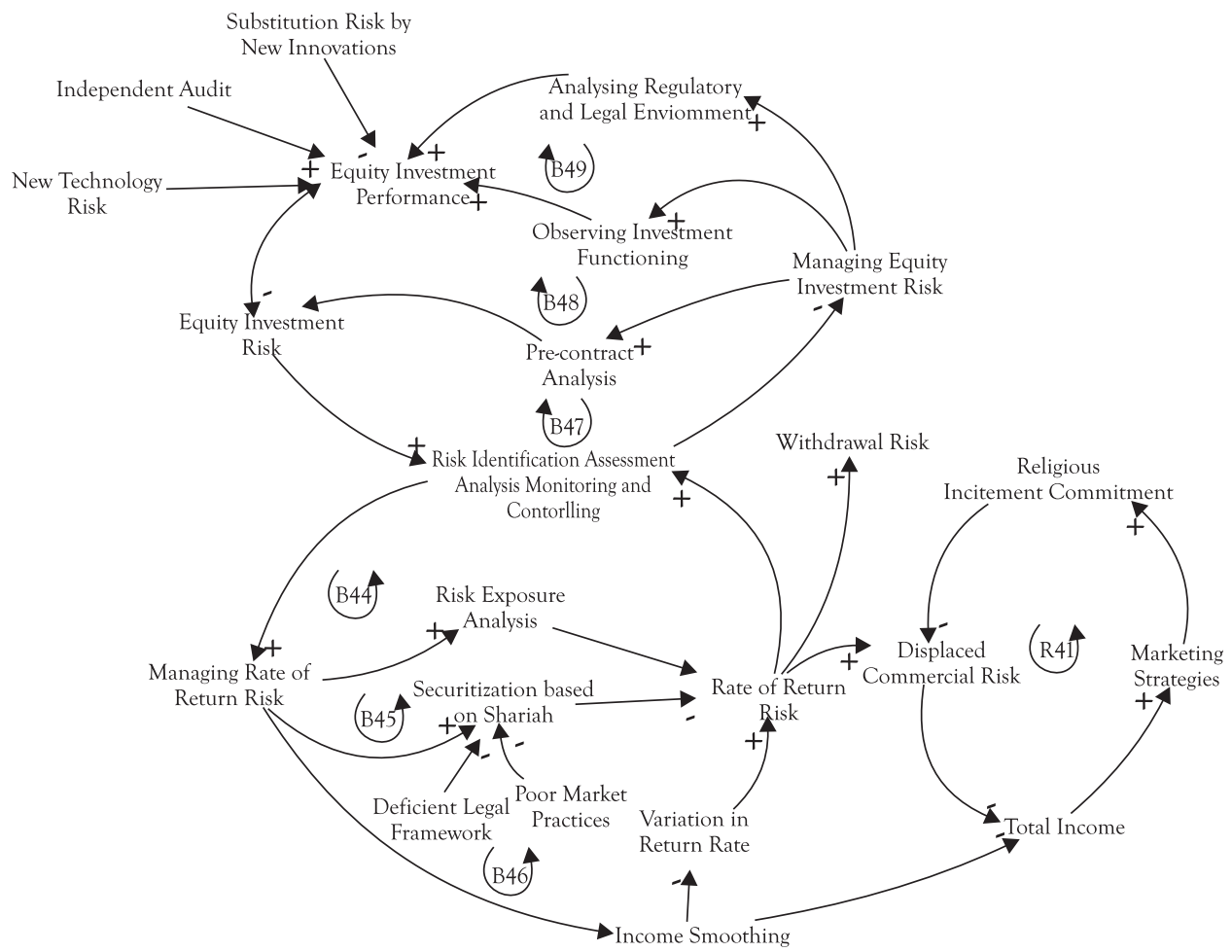

Figure 5: Validated SDM of Managing EIR and Managing RORR in IBIs

Figure 5 demonstrates the validated SDM of Managing EIR and Managing RORR in the Islamic Banking Institutions of Pakistan, which has already been explained separately for each loop. The figure provides a comprehensive understanding of the risk management framework of these Islamic Banking specific risks.

The results are in line with the homogeneity assumptions of the institutional theory presented by (DiMaggio \& Powell, 1983). This theory implies that homogeneous strategies can be taken as mandatory by coercive isomorphism through which legitimate authorities placed direct and indirect compressions on the institutions by using the measures like encouragement, direction, guidelines or instructions (Powell \& DiMaggio, 1991; Hudin \& Hamid, 2014; Buchko, 2011). For example, in Pakistan, all IBIs are instructed by the SBP to develop and implement a robust and detailed risk management framework to manage the rate of return risk and equity investment risk. 


\section{Conclusion}

In a country like Pakistan, where the dual banking system is operating, the development and stability of IBIs pose many problems. The system dynamic model of Rate of Return Risk and Equity Investment Risk management in the IBIs of Pakistan explains different strategies and procedures adopted by these institutions to cope with RORR and EIR to fulfil not only the regulatory obligations but also overcome the problems affecting their development and stability due to these risks. The interest rate has a very significant impact on the performance of IBIs despite the fact that the transactions of these institutions are interest-free. Moreover, a strong and established conventional banking system in the country also put extra pressure on the IBIs. Hence, exposing the IBIs to RORR leads to the threat of withdrawal risk and displaced commercial risk. The SDM indicates that IBIs manage RORR by conducting efficient risk exposure analysis through an efficient risk analysis team. Moreover, balance sheet practices like issuing Shariah-compliant securitization tranches are used to reduce the risk exposures. But, this Islamic securitization is modest because of the poor market practices and deficient legal framework. Furthermore, various marketing campaigns and Income Smoothing techniques are used by the Pakistani IBIs to counter the Displaced Commercial Risk and Withdrawal risk. The model also explains that these institutions manage equity investment risk through post-contract performance analysis, evaluating the regulatory and legal environment and pre-contract analysis.

This Qualitative SDM provides practical, constructive and productive understanding to the managers, policy-makers, regulators, shareholders and scholars regarding the RORR and EIR management mechanism of IBIs of Pakistan. This model also provides helpful and valuable insights to the local and international bodies to develop a more efficient and effective risk management mechanism of these Islamic banking specific risks by overcoming any deficiency in the existing system. In the end, the study concludes that identification and measurement of the RORR and EIR in IBIs in Pakistan need to be strengthened by developing appropriate methodology. Moreover, the practices adopted by these institutions to mitigate and control the risk exposures of RORR and EIR are a safer play instead of throwing caution to the wind.

\subsection{Implications, limitations and future prospects}

The causal loop diagrams (Figure 2, 4 and 5) intend to provide a detailed description of risk management structure in the local Islamic banking system regarding the rate of return risk and equity investment risk, where these banks are under the directions of SBP to develop and implement a robust and detailed risk management framework. Resultantly, these causal loop diagrams play a tremendous role for managers, researchers, stockholders, decision-makers and regulators to know risk manage- 
ment behaviour with reference to the rate of return risk and equity investment risk in the Pakistani Islamic banking system. Besides, the current research also intends to facilitate the Board of Directors and other Pakistani Islamic banking institutions' decision-makers to structure a detailed and beneficial risk management framework by improving their current system deficiencies. So, these diagrams are a source of information for overcoming any deficiency in the existing system of any Islamic banking institution. The current study intends to assist the central bank in monitoring and updating the regulatory framework of equity investment risk and rate of return risk management of IBIs.

The qualitative SDM provides a platform for further research. This model can be further tested through quantitative research. Future researchers can develop a questionnaire to examine the risk management practices quantitatively concerning the rate of return risk management and equity investment risk management. In the existing literature, the mixture of CLD and stock-flow diagrams have been incorporated by system dynamic methodology (Sterman, 2001). Nevertheless, the system dynamic framework of the stock-flow diagram has not been incorporated in existing research. The development of causal loop diagram is incorporated to document and comprehend the causality of interconnections among different Islamic banking risk exposures and practical risk management approaches. Hence, future researchers may find a potential to transmute the causal loop diagram into the stock-flow diagram.

\section{List of Abbreviations}

CLD Causal Loop Diagram

DCR Displaced Commercial Risk

EIR Equity Investment Risk

IBIs Islamic Banking Institutions

IFSB Islamic Financial Services Board

LIBOR London Interbank Offer Rate

RIAAMC Risk Identification, Assessment, Analysis, Monitoring and Controlling

RORR Rate of Return Risk

MEIR Managing Equity Investment Risk

MRRR Managing Rate of Return Risk 


\section{SBP State Bank of Pakistan \\ SDM System Dynamic Model \\ WR Withdrawal Risk}

\section{References}

Abdul Rahman, R., Tafri, F. H., \& Aljanadi, Y. (2010). Instruments and risks in Islamic financial institutions. Malaysian Accounting Review, 9(2), 11-21.

Abdullah, M., Shahimi, S., \& Ismail, A. G. (2011). Operational risk in Islamic banks: examination of issues. Qualitative Research in Financial Markets, 3(2), 131-151.

Abu Hussain, H., \& Al-Ajmi, J. (2012). Risk management practices of conventional and Islamic banks in Bahrain. The Journal of Risk Finance, 13(3), 215-239.

Ahmad, E., Khan, D., Akbar, N., Shoaib, M., \& Kifayat-Ullah. (2013). Pakistan’s Islamic banks risk management practices. European Journal of Banking and Finance, 10, 113-124.

Akkizidis, I. S., \& Khandelwal, S. K. (2008). Financial risk management for Islamic banking and finance. Palgrave Macmillan, UK.

Alasad, R., Motawa, I., \& Ougunlana, S. (2013). A system dynamics-based model for demand forecasting in PPP infrastructure projects - A case of Toll roads. Organization, technology $\mathcal{E}$ management in construction: an international journal, 6(2), 791-798.

Aldoseri, M., \& Worthington, A. C. (2016). Risk management in Islamic banking: An emerging market imperative. In S. Boubaker, B. Buchanan, \& D. K. Nguyen (Eds.), Risk management in emerging markets (pp. 229-252). United Kingdom: Emerald Group Publishing Limited. https://doi.org/10.1108/978$1-78635-452-520161020$

Ali, H. A., \& Naysary, B. (2014). Risk management practices in Islamic banks in Kuwait. Journal of Islamic Banking and Finance, 2(1), 123-148.

Black, K. (2012). Business statistics: For contemporary decision making, Donnelley, JC:. John Wiley \& Sons.

Bellinger, G. (2004). Systems thinking an operational perspective of the universe. Retrieved from https://bit. ly/2U99OZq

Boersma, K. (2011). The feasibility of systems thinking in biology education. Journal of Biological Education, 45(4), 190-197.

Buchko, A. (2011). Institutionalization, coercive isomorphism, and the homogeneity of strategy. Advances in Business Research, 2(1), 27-45.

Cebenoyan, A. S., \& Strahan, P. E. (2004). Risk management, capital structure and lending at banks. Journal of Banking $\mathcal{E}$ Finance, 28(1), 19-43. 
Dettmer, H. W. (1997). Goldratt's theory of constraints: A systems approach to continuous improvement. Wisconisn: ASQ Quality Press.

DiMaggio, P. J., \& Powell, W. W. (1983). The iron cage revisited: Institutional isomorphism and collective rationality in organizational Ffelds. American Sociological Review, 48(2), 147-160.

Eid, W. (2012). Mapping the risks and risk management practices in Islamic banking (Doctoral dissertation, Durham University, England). http://etheses.dur.ac.uk/3582/

Eid, W. K., \& Asutay, M. (2019). Mapping the risks and risk management practices in Islamic banking, France, John Wiley \& Sons.

El Tiby, A. M. (2011). Islamic banking: How to manage risk and improve profitability. France, John Wiley $\&$ Sons.

Errico, L., \& Sundararajan, V. (2002). Islamic financial institutions and products in the global financial system: Key issues in Risk management and challenges. IMF Working Paper Series, WP/02/192.

Farhan, M. (2019). Risk management in Islamic banking: Throwing caution to the wind or playing it safe. (PhD Thesis). University of the Punjab, Lahore, Pakistan. Retrieved from http://prr.hec.gov.pk/jspui/ bitstream/123456789/12056/1/Muhammad\%20Farhan\%20commerce\%202019\%20uop\%20 lhr\%20prr.pdf.

Farhan, M., \& Alam, H. M. (2018). Operational risk management in Islamic banking: A system thinking approach. Journal of Islamic Business and Management, 8(2), 450-464.

Goodman. (2016, February 27). Systems thinking: What, why, when, where, and how? The Systems thinker. Retrieved from https://thesystemsthinker.com/systems-thinking-what-why-when-where-and-how.

Greuning, H. van, \& Iqbal, Z. (2008). Risk analysis for Islamic banks. Washington, DC: World Bank.

Hafez, H. M. (2015). Risk management practices in Egypt: A comparison study between Islamic and conventional banks. Risk Governance and Control: Financial Markets $\mathcal{E}$ Institutions, 5(4), 257-270.

Hudin, N. S., \& Hamid, A. B. A. (2014). Drivers to the implementation of risk management practices: a conceptual framework. Journal of Advanced Management Science Vol, 2(3), 163-169.

Hassan, A. (2009). Risk management practices of Islamic banks of Brunei Darussalam. The Journal of Risk Finance, 10(1), 23-37. https://doi.org/10.1108/15265940910924472.

Hassan, W. M. (2011). Risk management practices: A comparative analysis between Islamic banks and conventional banks in the Middle East. International Journal of Academic Research, 3(3), 288-295.

Iqbal, Z., \& Mirakhor, A. (2011). An introduction to Islamic finance: Theory and practice. Asia, John Wiley \& Sons.

Islamic Financial Services Board. (2005). Guiding principles of risk management for institutions (other than Insurance Institutions) Offering only Islamic financial services. Retrieved from https://ifsb.org/maindoc.php. 
Jobst, A. (2007). Economics of Islamic finance and securitization. International Monetary Fund, Washington, DC.

Kapp, J. M., Simoes, E. J., DeBiasi, A., \& Kravet, S. J. (2017). A conceptual framework for a systems thinking approach to US population health. Systems Research and Behavioral Science, 34(6), 686-698.

Khalid, S., \& Amjad, S. (2012). Risk management practices in Islamic banks of Pakistan. The Journal of Risk Finance, 13(2), 148-159.

Khan, T., \& Ahmad, H. (2001). Risk management: An analysis of issues in Islamic financial Industry. Occasional Paper No. 5, Islamic Development Bank, Islamic Research and Training Institute, Jeddah.

Kim, D. H. (1992). Guidelines for drawing causal loop diagrams. The Systems Thinker, 3(1), 5-6.

Lee, J. (2008). Complexities of risk outweigh Basel II. Islamic Banking E Finance, August - September 2008, pp. 28-29.

Lee, S. W. (2015). Dividend policy and investment decisions of Korean banks. Review of European Studies, 7(3), 245-252.

Leischow, S. J., Best, A., Trochim, W. M., Clark, P. I., Gallagher, R. S., Marcus, S. E., \& Matthews, E. (2008). Systems thinking to improve the public's health. American Journal of Preventive Medicine, 35(2) 196-203.

Meadows, D. H. (2008). Thinking in Systems: A Primer. London: Chelsea Green Publishing.

Muhammad, A. D. (2016). Risk Management practices in Islamic banking institutions: A comparative study between Nigeria and Malaysia (Working Papers No. 2016-14). The Islamic Research and Teaching Institute (IRTI).

Myers, M. D. (2009). Qualitative research in business and management. Los Angeles: SAGE.

Powell, W. W., \& DiMaggio, P. J. (Eds.). (1991). The New institutionalism in organizational analysis (1 edition). Chicago: University of Chicago Press.

Ratnovski, L. (2013). Liquidity and transparency in bank risk management. Journal of Financial Intermediation, 22(3), 422-439.

Rahman, R. A., Ibrahim, Z., Tohirin, A., \& Suryaputri, A. D. M., Rossje Vitariamettawaty. (2016). Risk management practices in Islamic banking institutions: A comparative study between Malaysia and Indonesia. PONTE International Scientific Research's Journal, 72(12), 207-220.

Rehman, A. A. (2016). A comparative study of risk management practices between Islamic and conventional banks in Pakistan. (Doctoral dissertation, Cardiff Metropolitan University, United Kingdom).Retrieved from https://repository.cardiffmet.ac.uk/handle/10369/7915

Rehman, A. A., Benamraoui, A., \& Dad, A. M. (2018). A comparative study of Islamic and conventional banks' risk management practices: empirical evidence from Pakistan. Journal of Banking Regulation, 
19(3), 222-235.

SBP. (2008). Risk management guidelines for Islamic banking institutions. Retrieved from https://www.sbp. org.pk/ibd/2008/c1.htm.

Schoon, N. (2016). Modern Islamic banking: Products, processes in practice. United Kingdom, John Wiley \& Sons.

Shafique, O., Hassan, M. T., \& Hussain, N. (2013). Differences in the risk management practices of Islamic versus conventional financial institutions in Pakistan: An empirical study. The Journal of Risk Finance, 14(2), 179-196. https://doi.org/10.1108/15265941311301206.

Sherwood, D. (2002). Seeing the forest for the trees: A manager's guide to applying systems thinking. London: Nicholas Brealey.

Sterman, J. D. (2001). System dynamics modeling: Tools for learning in a complex world. California Management Review, 43(4), 8-25.

Thompson, K. (2015, May 18). Positivism and Interpretivism in social research. Retrieved May 9, 2018, from https://revisesociology.com/2015/05/18/positivism-interpretivism-

Wahyudi, I., Rosmanita, F., Prasetyo, M. B., \& Putri, N. I. S. (2015). Risk management for Islamic banks: Recent developments from Asia and the Middle East. Singapore. John Wiley \& Sons.

Zainol, Z., \& Kassim, S. Hj. (2012). A critical review of the literature on the rate of return risk in Islamic banks. Journal of Islamic Accounting and Business Research, 3(2), 121-137. https://doi. org/10.1108/17590811211265948. 